Article

\title{
Comparing "Leaf-to-Root", "Nose-to-Tail" and Other Efficient Food Utilization Options from a Consumer Perspective
}

\author{
Sina Nitzko * and Achim Spiller \\ Department of Agricultural Economics and Rural Development, University of Göttingen, \\ 37073 Göttingen, Germany \\ * Correspondence: snitzko@uni-goettingen.de
}

Received: 31 July 2019; Accepted: 29 August 2019; Published: 2 September 2019

check for updates

\begin{abstract}
The efficient use of natural raw materials is a key element of sustainable development and is also gaining importance in the food sector. Consumers are increasingly realizing that food is too valuable to be used only partially. However, consumer acceptance is an important precondition for establishing efficient food utilization options. A total of 470 German consumers were surveyed through an online-questionnaire where they had to evaluate three options each for the efficient use of plant-based foods as well as animal-based foods with respect to eight different criteria. The results show that the six options differed significantly regarding consumer acceptance. The efficient use of plant-based foods (especially non-standard fruits/vegetables and the "leaf-to-root" principle) was more accepted than the efficient utilization of animal-based foods. Furthermore, it can be seen that options using the by-products in a natural form were considered more acceptable than those which subject the by-products to some form of processing. These results provide an insight into the views of consumers on food waste reduction strategies, which are frequently debated in the sustainability discussion.
\end{abstract}

Keywords: efficient utilization; food consumption; consumer research; food by-products

\section{Introduction}

The efficient use of natural, renewable raw materials is a key element of sustainable development. The production of food, for example, is associated with high resource utilization. Not to utilize food as fully as possible for human nutrition is not only inefficient, but also results in unfavorable social, environmental, and economic effects on the sustainability of the food sector [1].

By-products are generated in varying amounts during the different stages of the value chain; for instance, in food retailing (e.g., fruits/vegetables with defects), in the food processing industry (e.g., pomace from the production of fruit juice), in food service (e.g., offal, skins and heads of fish) or at the end user or consumer stage (e.g., fruit peels). Although these by-products are often rich in valuable nutrients and would generally be perfectly suitable for human consumption, they are often used for other purposes or are disposed of [2].

While it was a matter of course in earlier times to use food holistically or more efficiently than nowadays [3], this practice has lost importance in the developed countries due to the existing surplus of food [4]. However, in recent times, a mindset change or rather a return to previous ideas has started, partly due to the increasing importance of sustainability in the food sector [5] and the public discussion about food waste and refuse [1]. It is being realized more and more that food is too valuable that only certain parts of it are used. Besides the sustainability-related advantages of an efficient use of food, there are also various options for saving costs and developing new products or dishes [4]. Different methods for the efficient use of both plant-based and animal-based foods are already known, which can be implemented at various stages of the value chain. 
The acceptance of consumers is an essential precondition not only for being able to utilize the various methods of efficiently using either plant- or animal-based foods but also for successfully establishing new products based on food by-products [6-8]. Some studies show that sustainability-related [9] and ethical aspects [10] have gained in importance in food consumption on the side of the consumer. In addition, there is also an increasing general awareness of the subject of food waste and a growing appreciation of food [11,12]. Nevertheless, based on people's culinary habits, the by-products of foods are still often regarded as waste [13] and are negatively associated by consumers (e.g., contamination) [14,15].

It is known that deficits of trust in the food industry on the side of the consumer [16] can have adverse effects on the acceptance of the various methods of efficiently using foodstuffs or even the development of new products using by-products from the value chain stage of the food processing industry. The use of by-products for food production can be associated with consumer concerns regarding the use of raw materials of lower quality for cost-saving or the production of products of reduced quality [8]. In addition, consumers can have reservations towards certain innovative technologies [17], which are sometimes used for the efficient utilization of by-products.

Against this background, six options of efficiently utilizing food, located at different stages of the value chain, will be presented and discussed in the following. Three methods for the efficient utilization of plant-based by-products will be considered: the "leaf-to-root" principle, non-standard fruits/vegetables, and the innovative production of valuable substances (by means of food and biotechnological processing techniques). The three methods for the efficient utilization of animal-based foods include the production of mechanically separated meat and reconstituted meat products (already established in the food industry), as well as the "nose-to-tail" principle (cf. Figure 1). In addition, due to the importance of consumer acceptance, the state of consumer-related research is discussed for each method.

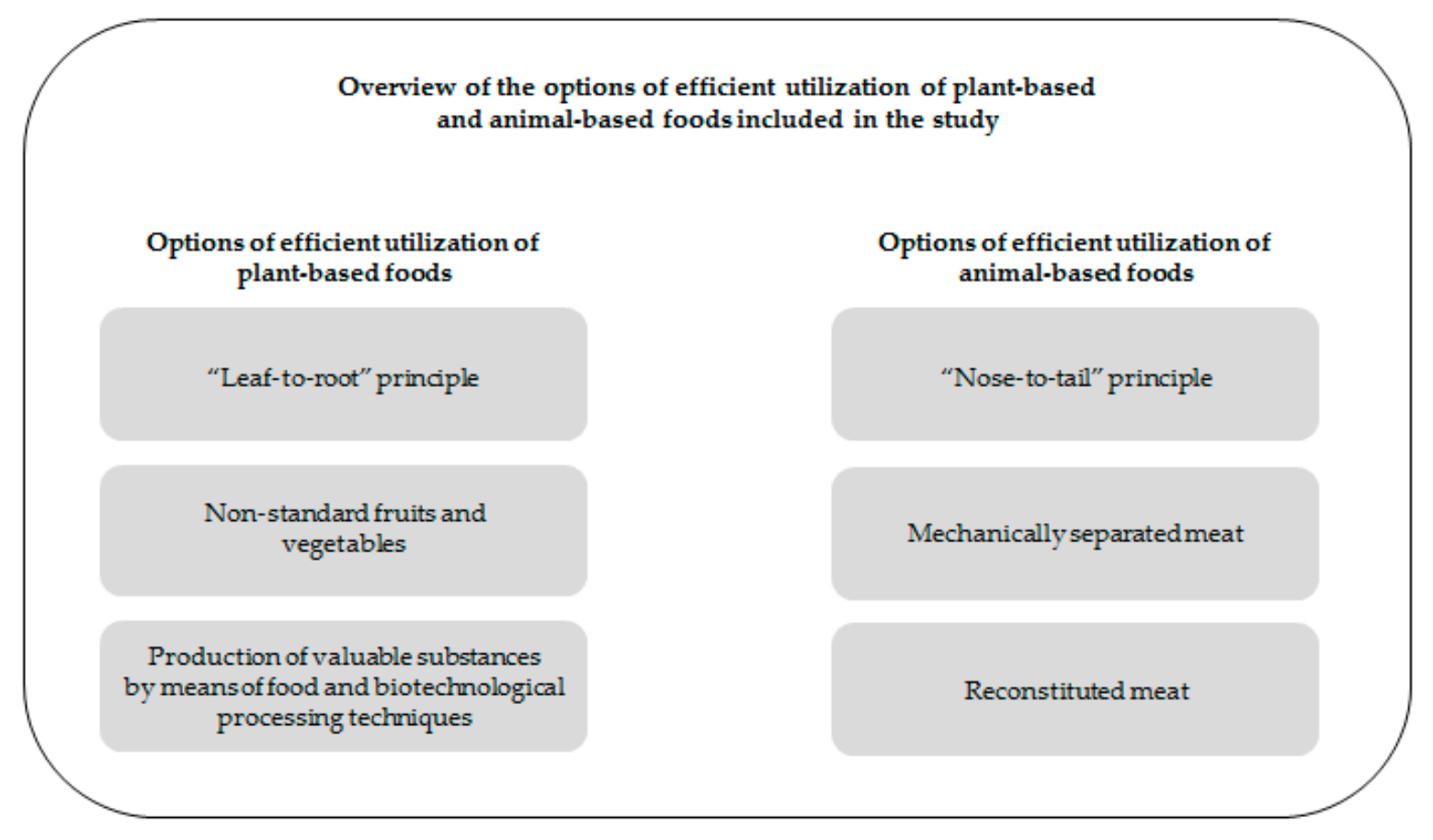

Figure 1. Options of efficient utilization of plant-based and animal-based foods used in the study (Source: authors' own illustration).

\subsection{Options for the Efficient Utilization of Plant-Based Foods}

The "leaf-to-root" principle is one method of efficiently utilizing plant-based foods [18]. It means the holistic utilization of agricultural plants; i.e., not only the "first cuts" (the parts of plants that are usually consumed) are used for human nutrition but also those parts which are otherwise thrown away (the so-called "second cuts"; e.g., peel, roots, leaves, stems, and stalks, etc.) $[18,19]$. The complete use 
of plants, which was common in households in earlier times, has been forgotten more and more [20]. Recently, the traditional, often forgotten knowledge about the holistic utilization of useful plants has been rediscovered and further developed. Thus "leaf-to-root" has developed into a culinary trend, which can be found in private households and in the gastronomy sector. While especially food websites provide information about the edibility and the processing of "second cuts" (e.g., www.leaf-to-root.com), there is a lack of scientific consumer-related studies.

Non-standard fruits and vegetables (aka "misfit" or "ugly" vegetables) do not comply with the set marketing standards and may therefore not be marketed. They are characterized by special features in their external appearance, which can relate to size, form, shape, color, condition, and defects [21]. In the European Union, ten types of fruits/vegetables are subject to special marketing standards; all other types are subject to general marketing standards [22]. Non-standard products are partly used for non-human food purposes (e.g., animal feed) and/or are partly left on the field or otherwise disposed of [23]. The problem of food losses due to non-standard fruits/vegetables has become subject to public discussion. Methods of efficiently using non-standard fruits and vegetables already exist at the retail stage [24], during food processing, in gastronomy, and in private households. The available consumer-related studies show that damage to the exterior of fruit rapidly attracts attention and that these products are rarely selected [25]. Moderately misfit fruits are accepted while consumer acceptance of extremely misfit products is low [26-28]. Moreover, differences in acceptance were observed with regard to the type of fruit/vegetable and the nature of the deviation from the standard. For instance, there is a higher willingness to buy non-standard lemons and eggplants than non-standard apples and carrots [28]. However, price reductions are necessary for the customer's decision to buy a non-standard product. Such discounts differ regarding the type of fruit/vegetable and the type of deviation from the accepted standard [e.g., average discount expectations: apple with spot: $67.1 \%$, crooked cucumber: 23.7\% [29]; irregularly shaped carrot: 30\%, irregularly sized carrot: 7\%; [26]]. Studies on consumer characteristics for the acceptance/purchase of non-standard fruits/vegetables show that an increased acceptance of or preference for non-standard products is associated with a higher awareness of food waste or a higher perceived importance of food waste [27,29], as well as environmental concerns [28].

The production of valuable substances for food production from plant-based by-products is another option for the efficient use of plant-based foods during food processing. In the food industry, large quantities of by-products (or secondary streams) are produced during the processing of plant material (e.g., potato peels). These are not used in human food production, while actually being suitable for it. Instead, they are often used for other purposes (e.g., animal feed, biogas production) [30,31]. Alternatively, such by-products have to be disposed of, which involves additional costs. The potential of the valuable substances contained in plant-based by-products has so far been insufficiently exploited [32]. An opportunity of using them for human nutrition is the production or extraction of new valuable substances (e.g., natural flavorings, dietary fibers, or enzymes, etc.) using food and biotechnological processing techniques [33-36]. These substances can in turn be used for food production. A good example of this is the growth of edible mushrooms (Basidiomycota) on plant-based by-products to produce various types of substances [37-39]. The plant-based by-products are pretreated [i.e., the cells are broken down mechanically [40] or electromagnetically [41]] before being used as a substrate. This pretreatment releases the intracellular nutrients for biotransformation by the edible mushrooms. The fungal biotransformation converts the nutrients contained in the substrate into other utilizable substances, which can then be extracted from the mushroom cultures [42]. One example of this method is the biotransformation of the lipids in oil press cake by Polyporus betulinus to produce pineapple aroma [43]. So far, there is a lack of studies that shed light on this topic from the consumer's point of view.

\subsection{Options for the Efficient Utilization of Animal-Based Foods}

"Nose-to-tail" means that as many parts as possible of a slaughtered animal are utilized. In principle, almost all parts of a carcass are suitable for the preparation of food, with the exception of fur, bristles, 
claws, eyelids, inner auditory canals, and the tissues around the area where the main blood vessels of the neck were severed for exsanguination. Which parts are considered as "edible" depends on culture, individual preferences, and social background [44,45]. The holistic utilization of slaughtered animals has been forgotten during the course of transformation towards a high degree of specialization in meat consumption which has taken place in recent decades. Consumers nowadays mostly prefer certain pieces of meat (fillet pieces), while many of the remaining parts (e.g., offal) are rejected or regarded as waste [3,4]. Recently, however, there has been a trend back to the holistic utilization of slaughtered animals, especially in gastronomy, and also in private households [46]. In a consumer study, "nose-to-tail" was evaluated positively by $75.4 \%$ of the respondents. The consumers in the study reported sensory and ethical aspects as well as economic and (occasionally) environmental reasons as motives for acceptance, while difficulties in obtaining slaughter by-products, sensory aspects, and a lack of knowledge regarding preparation were reported as reasons for the rejection of "nose-to-tail" [47].

The production of mechanically separated meat, which is practiced in the food processing industry, is another opportunity of efficient utilization. After an animal has been slaughtered, firstly, the high-quality pieces of meat (e.g., fillet) are removed. Then the meat adhering to the bones is detached by machine, leading to a change in the structure of the muscle fibers (dissolution). The resulting product is referred to as mechanically separated meat. Mechanically separated meat is not comparable to muscle meat [48]. It is used as raw material for the production of meat products and meat preparations [49]. In the USA as well as in the EU, mechanically separated meat may only be obtained from pigs and poultry and its use needs to be specifically labelled [50-53]. Consumer-related studies on mechanically separated meat are not as yet available.

The production of reconstituted meat (aka meat slurry or emulsified meat) is another option for the efficient utilization of slaughtered animals in the food processing industry. Reconstituted meat consists of small pieces of meat that are put together. The meat pieces are obtained after the carcass is butchered or cut (e.g., when cutting ham to size) [54]. The cohesion of the pieces and the new shape are achieved using different technological processes. Due to a mechanical pre-treatment of the meat pieces, their structure is loosened and the muscle protein emerges on the surface. The mass is then put into molds and subjected to a heat or freezing treatment. The protein that has leaked out on to the surface coagulates, so that the pieces of meat combine to form a larger piece. The use of enzymes, salts, and other binding systems is also possible [55]. Reconstituted meat is used, inter alia, for the production of ham, schnitzel, or chicken nuggets. Reconstituted meat must be labelled in the EU [46]. A consumer-related study has shown that consumers perceive reconstituted meat as a modification of the product identity and are skeptical [56]. These authors found also that unclear product declaration is associated with the danger of consumer deception.

In general, options for efficient utilization gain increasing importance in the food sector due to sustainability-related reasons. Although consumer acceptance is of high relevance for the long-term establishment of possibilities with regard to efficient utilization or products produced on the basis of by-products, there is a lack of studies that investigate this issue. As shown above, there are several consumer-related studies on non-standard fruits/vegetables available and individual ones have been conducted on "nose-to-tail" or reconstituted meat. However, there are no available consumer-related studies on the subject of mechanically separated meat, the "leaf-to-root" principle, or the production of valuable substances from plant-based by-products. In addition, every available study considers only one option of efficient utilization in combination with different consumer-related aspects. Accordingly, there is a lack of studies that directly compare consumer evaluations of different methods for the efficient utilization of foodstuffs based on defined criteria. The aim of the present study therefore, is a consumer evaluation of the aforementioned six methods of efficiently utilizing plant-based or animal-based foods. Due to the inclusion of different options of efficient utilization and the use of identical criteria, the present study enables an estimation of the acceptance of each method as well as a comparison of these different methods, which is in contrast to previous studies. 
Overall, the present study should provide an insight into the consumers evaluation of different options of efficient utilization of foods. Based on the study findings, conclusions regarding differences in acceptance depending on the respective option of efficient utilization can be drawn. In a further step, acceptance deficits and barriers can be investigated. Also, practical as well as theoretical implications for the further development of efficient food utilization or products that are produced on the basis of by-products can be derived.

\section{Materials and Methods}

\subsection{Questionnaire and Data Collection}

The present study is based on data that were collected via an online survey undertaken in April/May 2017. The probands were recruited through an external online panel provider using a standardized online questionnaire. The questionnaire, which was developed by the authors of the study, included defined questions and answer categories (a closed answer format was used). The online version of the questionnaire was programmed using the EFS Survey software (Unipark, Questback GmbH, Oslo, Norway). In the first part of the survey, the probands' sociodemographic data were collected.

The participants were then asked to evaluate three options of the efficient use of plant-based foods ("leaf-to-root" principle, non-standard fruits/vegetables, and production of valuable substances using food and biotechnological processing of plant-based by-products; cf. Section 1.1) and three options of the efficient use of animal-based foods ("nose-to-tail" principle, mechanically separated meat, and reconstituted meat; cf. Section 1.2).

For each of the six options, the participants received first an introductory text with information about the option. Each of the introductory texts was followed by a polarity profile to evaluate the option of utilization. The participants had to evaluate each option for eight criteria or dimensions, which were identified based on a previous literature research (appetizing vs. disgusting; hygienic vs. unhygienic; harmless for human health vs. risky for human health; high quality vs. low quality; responsible use of food vs. irresponsible use of food; promising for the future vs. not promising for the future; respectful vs. disrespectful towards farmers who keep animals/cultivate plants; economically profitable vs. economically unprofitable). The evaluation was made on a five-tier polarity scale ( $2=$ "fully correct" [e.g., high quality], $1=$ "rather correct" [e.g., high quality], $0=$ "neither one nor the other", $-1=$ "rather correct" [e.g., low quality], -2 = "fully correct" [e.g., low quality]). The scale was developed by the authors according to the work of Menold and Bogner [57], Prüfer et al. [58], Goldhammer and Hartig [59] and Giersdorf et al. [60]. Before the main survey started, a pretest was carried out.

It took about 15 minutes to complete the questionnaire. A total of 505 German consumers were surveyed. After cleansing (exclusion of 35 cases) the data of 470 probands was included in the final data analyses. Since each evaluation aspect was measured by only one item and only at one point of measurement (cross-sectional study), it is not possible to provide reliability measures. The content validity of each of the single-item scales was ensured by the fact that the formulation of the items was closely oriented to the definition of the construct.

\subsection{Sample Description}

To obtain representative results for the German population, quotas were set for age, gender, and education. The frequencies of the quotation variables achieved in the sample as well as the representative frequencies based on data of the Federal Statistical Office of Germany are presented in Table 1. The sample approximately represents the German population regarding age, gender, and education. The analyses of other sociodemographic variables revealed that $9.4 \%$ of the participants lived in their parents' household/with one parent, $27.3 \%$ lived alone in an apartment, $3.8 \%$ in a flat-sharing community, $30.7 \%$ together with a partner, $24.1 \%$ together with a partner and a child/children, and $4.7 \%$ with a child/children without a partner. Regarding professional qualifications, the analysis showed that $6.4 \%$ were doing vocational training/studying, $56.4 \%$ had a completed vocational training, $9.1 \%$ 
had a polytechnic degree, $16.2 \%$ had a university degree, $1.3 \%$ a doctorate, $8.7 \%$ had no professional qualification, and 1.9\% stated "other". Regarding the monthly net household income, the analysis showed that $11.6 \%$ had an income below $€ 500$ to $€ 899,37.3 \%$ an income between $€ 900$ and $€ 1,999$, $30.3 \%$ between $€ 2,000$ and $€ 3,199$, and $20.7 \% € 3,200$ and more.

Table 1. Percentage of frequencies in the proband sample as well as representative percentage of frequencies according to the data of the Federal Statistical Office of Germany regarding the variables age, gender, and education.

\begin{tabular}{|c|c|c|}
\hline Characteristic & $\begin{array}{l}\text { Percentage of } \\
\text { Frequencies in } \\
\text { the Sample }(\%)\end{array}$ & $\begin{array}{l}\text { Representative Percentage of } \\
\text { Frequencies according to the Federal } \\
\text { Statistical Office of Germany (\%) }\end{array}$ \\
\hline \multicolumn{3}{|l|}{ Gender $^{1}$} \\
\hline male & 48.9 & 48.8 \\
\hline female & 51.1 & 51.2 \\
\hline \multicolumn{3}{|l|}{ Age groups ${ }^{2}$} \\
\hline 18-24 years & 11.1 & 10.9 \\
\hline $25-29$ years & 8.3 & 9.4 \\
\hline 30-34 years & 8.7 & 9.7 \\
\hline 35-39 years & 9.4 & 9.7 \\
\hline 40-44 years & 9.8 & 9.1 \\
\hline $45-49$ years & 11.9 & 11.5 \\
\hline $50-54$ years & 14.3 & 13.8 \\
\hline $55-59$ years & 13.0 & 12.8 \\
\hline $60-65$ years & 13.6 & 13.0 \\
\hline \multicolumn{3}{|l|}{ Education $^{3}$} \\
\hline still in school & 1.3 & 1.1 \\
\hline certificate of secondary education & 25.1 & 25.4 \\
\hline general certificate of secondary education & 34.5 & 34.1 \\
\hline $\begin{array}{l}\text { advanced technical college entrance } \\
\text { qualification/university entrance diploma }\end{array}$ & 36.8 & 35.6 \\
\hline without school leaving certificate & 2.3 & 3.7 \\
\hline
\end{tabular}

${ }^{1}$ Federal Statistical Office of Germany. Zensus 2011-Bevölkerung in Gemeinden nach Geschlecht, Deutsche/Ausländer und fünf Altersgruppen-Erste Ergebnisse des Zensus 2011; Federal Statistical Office of Germany: Wiesbaden, Germany, 2013. ${ }^{2}$ Federal Statistical Office of Germany. Bevölkerung am 31.12.2012 nach Alters- und Geburtsjahren, Ergebnisse auf der Grundlage des Zensus 2011, Zensusdaten mit dem Stand vom 11.04.2014. Unpublished data (personal communication). Federal Statistical Office of Germany: Wiesbaden, Germany, 2014. ${ }^{3}$ Federal Statistical Office of Germany. Bevölkerung 2015 nach Alter und Bildungsabschluss. Unpublished data (personal communication). Federal Statistical Office of Germany: Wiesbaden, Germany, 2015.

\subsection{Statistical Analysis}

The analysis of the data was carried out using SPSS 24 (IBM Deutschland GmbH, Ehningen, Germany). The descriptive analyses included the calculation of the mean value and the standard deviation for each option of efficient utilization for each of the eight dimensions of the polarity profile (cf. Table 2). In order to examine the evaluation differences between the six options of efficient use on each of the eight dimensions, analyses of variance with repeated measurements were carried out. The sphericity as a prerequisite for the analysis of variance with repeated measurements was checked by means of the Mauchly test [61]. When the sphericity assumption was violated, the Greenhouse-Geisser correction was used.

If a significant difference could be identified using the analysis of variance with repeated measurement, a post hoc test (post hoc test with Bonferroni correction) was used to determine which evaluations differ significantly. 
Table 2. Results of the descriptive analysis [mean value (M) and standard deviation (SD)] are shown for each of the six options of efficient utilization as well as the results of the analyses of variance and post hoc tests.

\begin{tabular}{|c|c|c|c|c|c|c|c|c|}
\hline Criteria & $\begin{array}{c}\text { (A) } \\
\text { Reconstituted } \\
\text { Meat M (SD) }\end{array}$ & $\begin{array}{c}\text { (B) } \\
\text { “Nose-To-Tail” } \\
\text { Principle } \\
\text { M (SD) } \\
\end{array}$ & $\begin{array}{c}\text { (C) } \\
\text { Mechanically } \\
\text { Separated Meat } \\
\text { M (SD) }\end{array}$ & $\begin{array}{c}\text { (D) } \\
\text { Non-Standard } \\
\text { Fruits/Vegetables } \\
\text { M (SD) }\end{array}$ & $\begin{array}{c}\text { (E) } \\
\text { “Leaf-To-Root” } \\
\text { Principle } \\
\text { M (SD) }\end{array}$ & $\begin{array}{c}\text { (F) Valuable } \\
\text { Substances from } \\
\text { Plant-Based } \\
\text { By-Products M (SD) }\end{array}$ & $\begin{array}{c}\text { Results of the } \\
\text { Analyses of Variance } \\
\text { with Repeated } \\
\text { Measurement }\end{array}$ & Results of the Post Hoc Tests ${ }^{9}$ \\
\hline Appetizing quality ${ }^{1}$ & $-0.48(1.02)$ & $0.01(1.14)$ & $-0.28(1.01)$ & $1.04(0.89)$ & $0.73(0.98)$ & $0.21(1.01)$ & $\begin{array}{c}F=196.068 \\
p=0.000\end{array}$ & $\begin{array}{c}\mathrm{A}<\mathrm{B}, \mathrm{A}<\mathrm{C}, \mathrm{A}<\mathrm{D}, \mathrm{A}<\mathrm{E}, \mathrm{A}<\mathrm{F}, \mathrm{B}>\mathrm{C}, \mathrm{B}<\mathrm{D}, \mathrm{B}<\mathrm{E}, \\
\mathrm{C}<\mathrm{D}, \mathrm{C}<\mathrm{E}, \mathrm{C}<\mathrm{F}, \mathrm{D}>\mathrm{E}, \mathrm{D}>\mathrm{F}, \mathrm{E}>\mathrm{F}\end{array}$ \\
\hline Hygiene $^{2}$ & $0.00(1.00)$ & $0.40(1.00)$ & $0.08(.97)$ & $1.17(0.94)$ & $0.86(0.98)$ & $0.55(1.00)$ & $\begin{aligned} F & =144.747 \\
p & =0.000\end{aligned}$ & $\begin{array}{c}\mathrm{A}<\mathrm{B}, \mathrm{A}<\mathrm{D}, \mathrm{A}<\mathrm{E}, \mathrm{A}<\mathrm{F}, \mathrm{B}>\mathrm{C}, \mathrm{B}<\mathrm{D}, \mathrm{B}<\mathrm{E}, \\
\mathrm{C}<\mathrm{D}, \mathrm{C}<\mathrm{E}, \mathrm{C}<\mathrm{F}, \mathrm{D}>\mathrm{E}, \mathrm{D}>\mathrm{F}, \mathrm{E}>\mathrm{F}\end{array}$ \\
\hline Health harmlessness ${ }^{3}$ & $0.29(1.06)$ & $0.62(1.05)$ & $0.27(1.00)$ & $1.48(0.82)$ & $1.07(0.98)$ & $0.57(1.04)$ & $\begin{array}{c}\mathrm{F}=149.514 \\
\mathrm{p}=0.000\end{array}$ & $\begin{array}{c}\mathrm{A}<\mathrm{B}, \mathrm{A}<\mathrm{D}, \mathrm{A}<\mathrm{E}, \mathrm{A}<\mathrm{F}, \mathrm{B}>\mathrm{C}, \mathrm{B}<\mathrm{D}, \mathrm{B}<\mathrm{E}, \\
\mathrm{C}<\mathrm{D}, \mathrm{C}<\mathrm{E}, \mathrm{C}<\mathrm{F}, \mathrm{D}>\mathrm{E}, \mathrm{D}>\mathrm{F}, \mathrm{E}>\mathrm{F}\end{array}$ \\
\hline Quality ${ }^{4}$ & $-0.78(1.07)$ & $0.23(1.07)$ & $-0.31(1.06)$ & $1.10(0.94)$ & $0.74(1.04)$ & $0.26(1.00)$ & $\begin{aligned} F & =255.322 \\
p & =0.000\end{aligned}$ & $\begin{array}{c}\mathrm{A}<\mathrm{B}, \mathrm{A}<\mathrm{C}, \mathrm{A}<\mathrm{D}, \mathrm{A}<\mathrm{E}, \mathrm{A}<\mathrm{F}, \mathrm{B}>\mathrm{C}, \mathrm{B}<\mathrm{D}, \mathrm{B}<\mathrm{E}, \\
\mathrm{C}<\mathrm{D}, \mathrm{C}<\mathrm{E}, \mathrm{C}<\mathrm{F}, \mathrm{D}>\mathrm{E}, \mathrm{D}>\mathrm{F}, \mathrm{E}>\mathrm{F}\end{array}$ \\
\hline Responsible use of food ${ }^{5}$ & $-0.10(1.13)$ & $0.84(1.09)$ & $0.35(1.07)$ & $1.45(0.90)$ & $1.26(0.90)$ & $0.73(1.06)$ & $\begin{array}{c}\mathrm{F}=207.067 \\
\mathrm{p}=0.000\end{array}$ & $\begin{array}{c}\mathrm{A}<\mathrm{B}, \mathrm{A}<\mathrm{C}, \mathrm{A}<\mathrm{D}, \mathrm{A}<\mathrm{E}, \mathrm{A}<\mathrm{F}, \mathrm{B}>\mathrm{C}, \mathrm{B}<\mathrm{D}, \\
\mathrm{B}<\mathrm{E}, \mathrm{C}<\mathrm{D}, \mathrm{C}<\mathrm{E}, \mathrm{C}<\mathrm{F}, \mathrm{D}>\mathrm{E}, \mathrm{D}>\mathrm{F}, \mathrm{E}>\mathrm{F}\end{array}$ \\
\hline Future potential ${ }^{6}$ & $0.02(1.11)$ & $0.68(1.05)$ & $0.37(1.02)$ & $1.28(0.88)$ & $1.05(0.98)$ & $0.88(0.96)$ & $\begin{array}{l}\mathrm{F}=134.835 \\
\mathrm{p}=0.000\end{array}$ & $\begin{array}{c}\mathrm{A}<\mathrm{B}, \mathrm{A}<\mathrm{C}, \mathrm{A}<\mathrm{D}, \mathrm{A}<\mathrm{E}, \mathrm{A}<\mathrm{F}, \mathrm{B}>\mathrm{C}, \mathrm{B}<\mathrm{D}, \\
\mathrm{B}<\mathrm{E}, \mathrm{B}<\mathrm{F}, \mathrm{C}<\mathrm{D}, \mathrm{C}<\mathrm{E}, \mathrm{C}<\mathrm{F}, \mathrm{D}>\mathrm{E}, \mathrm{D}>\mathrm{F}, \mathrm{E}>\mathrm{F}\end{array}$ \\
\hline $\begin{array}{l}\text { Respect towards far- mers who } \\
\text { keep ani- mals/cultivate plants }{ }^{7}\end{array}$ & $-0.23(1.09)$ & $0.65(1.13)$ & $0.31(1.00)$ & $1.35(0.96)$ & $1.18(0.96)$ & $0.68(1.05)$ & $\begin{array}{c}\mathrm{F}=204.639 \\
\mathrm{p}=0.000\end{array}$ & $\begin{array}{c}\mathrm{A}<\mathrm{B}, \mathrm{A}<\mathrm{C}, \mathrm{A}<\mathrm{D}, \mathrm{A}<\mathrm{E}, \mathrm{A}<\mathrm{F}, \mathrm{B}>\mathrm{C}, \mathrm{B}<\mathrm{D}, \mathrm{B}<\mathrm{E}, \\
\mathrm{C}<\mathrm{D}, \mathrm{C}<\mathrm{E}, \mathrm{C}<\mathrm{F}, \mathrm{D}>\mathrm{E}, \mathrm{D}>\mathrm{F}, \mathrm{E}>\mathrm{F}\end{array}$ \\
\hline Economic profitability ${ }^{8}$ & $1.05(1.07)$ & $1.06(1.06)$ & $0.86(1.06)$ & $1.16(1.01)$ & $1.17(0.96)$ & $0.98(0.97)$ & $\begin{array}{l}F=9.653 \\
p=0.000\end{array}$ & $\mathrm{~A}>\mathrm{C}, \mathrm{B}>\mathrm{C}, \mathrm{C}<\mathrm{D}, \mathrm{C}<\mathrm{E}, \mathrm{D}>\mathrm{F}, \mathrm{E}>\mathrm{F}$ \\
\hline
\end{tabular}

${ }^{1}$ Scale from (2) = appetizing-fully correct, $1=$ appetizing-rather correct, $(0)=$ neither the one nor the other, $(-1)=$ disgusting-rather correct, $(-2)$ disgusting-fully correct ${ }^{2}$ Scale from $(2)=$ hygienic-fully correct, $1=$ hygienic-rather correct, $(0)=$ neither the one nor the other, $(-1)=$ unhygienic-rather correct, $(-2)$ unhygienic-fully correct ${ }^{3}$ Scale from $(2)=$ harmless for human health-fully correct, $1=$ harmless for human health- rather correct, $(0)=$ neither the one nor the other, $(-1)=$ risky for human health-rather correct, $(-2)$ risky for human health-fully correct ${ }^{4}$ Scale from (2) = high quality-fully correct, $1=$ high quality- rather correct, $(0)=$ neither the one nor the other, $(-1)=$ low quality-rather correct, $(-2)$ low quality-fully correct ${ }^{5}$ Scale from $(2)=$ responsible use of food-fully correct, $1=$ responsible use of food-rather correct, $(0)=$ neither the one nor the other, $(-1)=$ irresponsible use of food-rather correct, $(-2)$ irresponsible use of food-fully correct ${ }^{6}$ Scale from $(2)=$ promising for the future-fully correct, $1=$ promising for the future- rather correct, $(0)=$ neither the one nor the other, $(-1)=$ not promising for the future-rather correct, $(-2)$ not promising for the future-fully correct ${ }^{7}$ Scale from $(2)=$ respectful towards farmers who keep animals/cultivate plants-fully correct, $1=$ respectful towards farmers who keep animals/cultivate plants-rather correct, $(0)=$ neither the one nor the other, $(-1)=$ disrespectful towards farmers who keep animals/cultivate plants-rather correct,$(-2)=$ disrespectful towards farmers who keep animals/cultivate plants-fully correct ${ }^{8}$ Scale from $(2)=$ economically profitable-fully correct, $1=$ economically profitable-rather correct, $(0)=$ neither the one nor the other, $(-1)=$ economically unprofitable-rather correct, $(-2)$ economically unprofitable-fully correct ${ }^{9}$ The differences between the measurements that were found to be significant are outlined. 


\section{Results}

\subsection{Consumer Evaluation of the six Options for the Efficient Utilization of Food}

As can be seen in Table 2, the mean values for appetizing quality vary between -0.48 (reconstituted meat) and 1.04 (non-standard fruits/vegetables), for health harmlessness between 0.29 (reconstituted meat) and 1.48 (non-standard fruits/vegetables), and for hygiene between 0.00 (reconstituted meat) and 1.17 (non-standard fruits/vegetables). The dimension quality lies between -0.78 (reconstituted meat) and 1.10 (non-standard fruits/vegetable). The average evaluations for the responsible use of foods are between -0.10 (reconstituted meat) and 1.45 (non-standard fruits/vegetables), while those of the future potential are between 0.02 (reconstituted meat) and 1.28 (non-standard fruits/vegetables). The evaluations regarding respect towards farmers range between -0.23 (reconstituted meat) and 1.35 (non-standard fruits/vegetables). The mean values for economic profitability lie between 0.86 (mechanically separated meat) and 1.17 ("leaf-to-root").

\subsection{Comparison of the Options for the Efficient Utilization of Plant-based Foods}

The mean values of non-standard fruits/vegetables of the seven dimensions appetizing quality, health harmlessness, hygiene, quality, responsible use of food, future potential, and respect towards farmers are significantly higher than for both "leaf-to-root" and the production of valuable substances from plant-based by-products. In addition, "leaf-to-root" shows significantly higher mean values in comparison to the production of valuable substances from plant-based by-products for all of these dimensions. Regarding the eighth dimension, economic potential, both non-standard fruits/vegetables and "leaf-to-root" have significantly higher mean values than the production of valuable substances from plant-based by-products (cf. Table 2).

\subsection{Comparison of the Options for the Efficient Utilization of Animal-based Foods}

"Nose-to-tail" shows significantly higher mean values for the seven dimensions appetizing quality, health harmlessness, hygiene, quality, responsible use of foods, future potential, and respect towards farmers than either reconstituted meat or mechanically separated meat. Significantly higher mean values for mechanically separated meat were found for the five dimensions appetizing quality, quality, responsible use of foods, future potential, and respect towards farmers than for reconstituted meat. Again, the results for the eighth dimension-economic profitability-stand out: both reconstituted meat and "nose-to-tail" have significantly higher mean values than the mean value of mechanically separated meat (cf. Table 2).

\subsection{Comparison of the Options for the Efficient Utilization of Plant-based and Animal-based Foods}

The mean values of non-standard fruits/vegetables and "leaf-to-root" are significantly higher for the seven dimensions appetizing quality, health harmlessness, hygiene, quality, responsible use of food, future potential, and respect towards farmers, than of all three possibilities for the efficient utilization of animal-based foods. The production of valuable substances from plant-based by-products has significantly higher mean values for these dimensions than both mechanically separated meat and reconstituted meat. In contrast, the production of valuable substances has only one dimension where it was found to be higher than "nose-to-tail"; namely, with regard to future potential. With respect to the eighth dimension-economic profitability-both non-standard fruits/vegetables and "leaf-to-root" evinced significantly higher mean values than mechanically separated meat (cf. Table 2).

\section{Discussion}

\subsection{Consumer Evaluations of the six Options for the Efficient Utilization of Foods}

Non-standard fruits/vegetables were evaluated as being rather of higher quality, rather hygienic, (rather) harmless for health, and rather appetizing by the participants in the study. The probands 
had slight reservations with respect to the non-standard fruits/vegetables, although they only differ in external appearance from products that conform to the standards, not in their intrinsic qualities, regarding food safety [1,62] and taste [26]. Modern consumers are used to finding fruits/vegetables in stores without any or with minimal visual deficits [63] and over time, consumers have come to link external appearance with the evaluation of food quality [64], food safety [26,62], and taste [26,29]. It is known that consumers extrapolate from visual suboptimality to a reduced quality [63] and food safety [29]. In addition, even sensory evaluation can be influenced by suboptimal appearance [65]. In general, fruits and vegetables are regarded as important sources of nutrients and are health-promoting. Information about the health benefits of non-standard fruits/vegetables (e.g., lower pesticide use) is associated with an increased acceptance and willingness to buy [66]. Consumer concerns could arise if they associate suboptimal appearance with, inter alia, genetic modifications [26]. The use of non-standard fruits/vegetables was regarded by the probands in the present study as being a (rather) responsible use of food and as rather promising for the future. These results are in line with other studies that have shown an increasing sustainability awareness in the consumer with respect to food consumption (e.g., [9]). Especially an awareness of the problem of food waste is a prerequisite for the acceptance of non-standard fruits/vegetables, whereby the consumption of these products needs to be recognized as a concrete solution for the problem of food waste [26,27]. In addition, the use of non-standard fruits/vegetables was regarded by the probands as being (rather) respectful towards farmers and rather economically profitable. The production of fruits and vegetables requires a great deal of energy, manpower, and resources [67]. Despite the high quality of non-standard fruits/vegetables [1,62], these are often not used for human nutrition, but for other purposes or are disposed of [68]. This is associated with financial losses for the farmers [69]. Even if consumers expect a discount on the purchase of non-standard fruits/vegetables [26,29], the profits from the use for human nutrition are still higher than for alternative marketing channels $[64,70]$.

The probands had an ambivalent to rather positive position with regard to both appetizing quality and quality to "leaf-to-root". Culture and tradition, as well as the related habits and familiarity with certain foods, are of importance in determining which types of food are consumed [13]. For this reason, many plant "second cuts" are regarded as less high-quality residues that need to be disposed of [4]. In addition, many of the "second cuts" are fibrous, tough, or bitter when raw and they need to be processed to become palatable [71]. Previous positive consumer experiences with the consumption of "second cuts" (e.g., apple with peel, lemon peel in a cake) can have a positive effect on the evaluation of appetizing quality and quality. In addition, "second cuts" are being more often used for dishes in sophisticated gastronomy [20], which can have a positive effect on their image. "Leaf-to-root" was evaluated by the probands as being rather harmless to health. In general, the skins of drupes or stone fruits and pome fruits are edible; most of their vitamins are even found just under the skin. However, plant parts that are usually not consumed were previously rarely tested for pesticide residues [19]. The available studies show that a considerable proportion of consumers have generally health-related concerns regarding pesticide residues (e.g., [72]). Furthermore, no relevant data is available for various "second cuts" so an expert evaluation of any possible consumption risks is not possible. However, there is evidence of health risks being associated with some plants or parts thereof [19]. "Leaf-to-root" was evaluated by the participants in the present study as a rather responsible use of foods as well as rather promising for the future. Due to the increasing public discussion about food waste [1], the use of food is gaining in appreciation [11]. The "leaf-to-root" concept provides one method of reducing food waste [73]. In addition, the use of "second cuts" opens up new opportunities for innovative dishes, which underlines its potential for the future. "Leaf-to-root" was also evaluated by the probands as being rather respectful towards farmers. A complete utilization of fruits and vegetables acknowledges the expenditures which are associated with cultivation [67]. However, there is one limitation as plant parts that are usually not intended for human consumption are treated differently in agriculture than "first cuts". In conventional agriculture, "second cuts" can contain higher pesticide residues [19]; while in organic agriculture, there is the possibility of contamination with farm manure [73]. The known 
possible risk of contamination may also have influenced the probands' ambivalent to rather positive attitude to hygiene with respect to this option. "Leaf-to-root" was also evaluated as being rather economically profitable by the study's participants. Costs can be saved by using "second cuts" instead of "first cuts" as a basis for meal preparation. Furthermore, disposal costs can be reduced through the holistic use of plants.

The production of valuable substances from plant-based by-products was evaluated by the probands as being neither appetizing nor disgusting. An available study shows that it is difficult for consumers to estimate the risks and benefits that are associated with innovative food technologies and foodstuffs [74]. However, it is also known that products produced by new technologies can lead to concerns and uncertainties among consumers [6], which can have a negative impact on taste expectations $[75,76]$. With regard to the health aspect, the probands' evaluation of the production of valuable substances from plant-based by-products lay between "neither harmless nor risky for human health" and "rather harmless for human health". In a study by Hengse and Bücking [77], $40 \%$ of the respondents also had an indifferent position (39\% don't agree at all/agree a bit; $22 \%$ agree completely/agree somewhat) when asked about the rejection of technical innovations due to feared health-damaging consequences. As already mentioned above, new food technologies and foods can give rise to consumer concern. Innovations may involve unknown, potentially harmful risks that are perceived to be "beyond one's control" by consumers [6]. The probands had an ambivalent to rather positive position with regard to the responsible use of foods and the future potential in relationship to the production of valuable substances from plant-based by-products. Due to the growing production figures in the fruit and vegetable processing sector, the quantity of by-products will increase [30]. Alternative (non-human food) usage would not sufficiently exploit the potential of the constituents [32]. Although there are concerns on the consumer side about new food technologies [6], their need is recognized, as strategies for resource-saving production were evaluated as being important by $85 \%$ of the consumers in one study and $68 \%$ considered the use of residual materials to produce other new types of products in the future food production to be important [77]. The extraction of valuable substances from plant-based by-products was also evaluated as rather economically profitable by the probands. The disposal of secondary streams is associated with costs for food-processing companies [30]. Through their use, however, new products such as food additives can be developed [4,43]. Overall, the importance of processed foods is increasing [78] so that there is also a need for food additives. Regarding the hygiene of the production of valuable substances from plant-based by-products, the present study's probands rated this as ambivalent to rather positive. Certainly, in general, plant-based by-products are prone to rapid microbial spoilage [30], but they do not spoil and so become waste if they are stored and handled correctly [4]. The probands also gave an ambivalent evaluation regarding quality of the valuable substances produced from plant-based by-products. This is understandable as, all in all, the production of valuable substances from plant-based by-products or their use in food production is not known to the consumer, therefore they cannot integrate this type of food into their existing cognitive schemes [79], making a clear evaluation difficult for them. The probands' evaluation of the respect towards farmers is ambivalent to rather positive. The use of by-products is most probably regarded as respectful by the probands, because there are high quality requirements placed on the fruits/vegetables used for industrial processing [62]. Their ambivalence may be due to the fact that consumers do not regard many of the by-products as raw materials in the sense of agricultural products that are produced by farmers although in some cases, there is a high proportion of by-products produced during food processing.

"Nose-to-tail" was evaluated by the probands in this study as neither appetizing nor disgusting. In general, the holistic consumption of slaughtered animals is associated with new taste experiences [44]. However, it is known that people's food choices are determined by habits and past behavior [80]. Due to the fact that the consumption of prime cuts is predominant nowadays, consumers gain hardly any experiences with the consumption of the remaining parts of a carcass. It is known that older people evaluate "nose-to-tail" more positively, because they have a greater familiarity with this 
principle (e.g., consumption of offal in childhood) [81]. In addition, there are differences in acceptance depending on the particular animal part. The closer the connection between the part and the animal or the more a piece of meat looks like the animal, the less appealing it is [82]. The probands rated "nose-to-tail" between "neither harmless nor risky for human health" and "rather harmless for human health". In general, edible animal by-products contain important nutrients [83]. However, the offal of animals may contain higher levels of heavy metals than muscle meat [84] and on the consumer side, there are contamination-related concerns about such food $[85,86]$. Indeed, meat and meat products are among the foods that are most frequently avoided due to the alleged high contamination with undesirable substances [86]. The probands' evaluations of "nose-to-tail" regarding the responsible use of foods, future potential, and respect towards farmers varied between ambivalent to rather positive. The available studies reveal not only an increasing consumer appreciation of food [11] but also an increase in the importance of animal welfare [87] and environmental aspects [88] in food consumption. "Nose-to-tail" can be considered as being more responsible in comparison to the widespread preference for prime cuts, which is associated with the production of a significant amount of by-products. Such by-products are little used for human nutrition despite their high nutrient content, which is ethically problematical [89]. "Nose-to-tail" would help to deal with the increasing demand for meat. In addition, the need to expand animal production with its negative ecological consequences to cover this increasing demand would be reduced [3,47]. Furthermore, the need for the development of breeding lines for farm animals which are aimed at covering the demand for specific parts (e.g., broad-breasted turkeys), but are associated with adverse effects on animal health [3], would also be reduced. The probands gave an ambivalent evaluation regarding quality of "nose-to-tail". In the course of the specialization of meat consumption in fillet pieces, the range of meat products of equivalent quality has become to be regarded as "standard", with the so-called "base" pieces being regarded as more inferior [3]. The consumption of offal is traditionally regarded as a less price-intensive option of nutrition [90], while the consumption of "prime cuts" is associated with higher prices and wealth consumption [47]. Indeed, from the consumer's point of view, the price could act as a quality indicator, so that a lower price is associated with lower quality [91]. The consumer perception of by-products as being more inferior can also have had an influence on the ambivalent to rather positive hygiene-related evaluation of "nose-to-tail" found in the present study. It has been shown that the availability of the meat of a species in stores is an indicator for the safety of the food [92]. Accordingly, the lack of availability of parts such as offal in stores could be associated with food safety problems. The holistic use of slaughtered animals was also seen as being rather economically profitable by the participants in the present study. This underlines the results of a previous study in which consumers noted economic aspects as reasons for the preference of "nose-to-tail" [47]. In general, meals can be prepared more economically if everything is used. It should be noted that some by-products are considered delicacies in other cultures, so that higher prices are achievable [93].

With regard to appetizing quality, health harmlessness, and hygiene, the probands in the present study had an ambivalent attitude towards mechanically separated meat. Due to health risks (BSE-inducing prions), only mechanically separated meat from pigs and poultry may be obtained throughout the EU [94,95]. Although specific hygiene requirements apply to the production of mechanically separated meat and the used raw materials [48], mechanically separated meat is often regarded as an inferior ingredient from the consumer's point of view [96]. The reasons for this not only could be the media reports about mechanically separated meat of poor quality (e.g., [97]), but also the lack of methods for the detection of risk material in the end product [98] and the risk of bone abrasion [96]. In addition, it has been shown that the high degree of processing of mechanically separated meat [99] and the contained additives [100] have a negative impact on the consumers' evaluation of quality. As such, the quality-related evaluation of the probands being ambivalent to rather negative is understandable. The present study's participants rated the responsible use of foods as well as their future potential as being ambivalent to rather positive for mechanically separated meat. Although as previously stated there are concerns regarding mechanically separated meat on the consumer side, it is known that if the hygiene 
and declaration regulations are observed, mechanically separated meat can be regarded as a sustainable and ethically responsible option $[49,96]$. If the option of producing mechanically separated meat is not used, the slaughter of millions more farm animals per year would be necessary. This would be associated with negative ecological consequences [49] and increased food waste [101]. The probands considered the production of mechanically separated meat to be neither respectful nor disrespectful to being rather respectful towards farmers. The holistic use of slaughtered animals is an efficient use of the carcass and so appreciates the high expenses and resource use that are associated with the production of animal-based foods [102]. However, various media reports on the disregard of hygiene and declaration requirements have promoted a critical evaluation of mechanically separated meat by the consumer, which may well then be extended to the entire value chain, including the farmers. Regarding the economic profitability of using mechanically separated meat, the attitude of the probands was ambivalent to rather positive. Compared to the costly disposal or alternative uses of such material, the production of mechanically separated meat for human nutrition is an economically profitable option [101]. The economic efficiency of meat processing can be significantly increased by using mechanically separated meat as a raw material for meat products and preparations [49].

Regarding appetizing quality, the probands' evaluation of reconstituted meat was found to be somewhere between "neither appetizing nor disgusting" and "rather disgusting". The evaluation could have been influenced by negatively connoted media reports, in which the use of reconstituted meat without an appropriate declaration was disclosed (e.g., [103]). In addition, reconstituted meat is often mentioned in connection with food imitations, which have a lower meat content and have been critically discussed in the media [e.g., "cheap disgusting stuff"; [104] (p. R4)]. These discussions, as well as reports on the use of inferior pieces of meat (e.g., [105]), could also have contributed to the probands' ambivalent attitude towards hygiene. Although the specifications for the production of reconstituted meat say that only pieces of meat, not minced, chopped, or similarly processed meat is allowed to be used [55], the probands gave an ambivalent to rather negative quality evaluation. This view may also have been influenced by the critical media reports already mentioned. In addition, reconstituted meat is a processed product, which can be produced with the use of binding agents [55]. A recently published review by Román et al. [106] reveals how important perceived naturalness is for consumers (e.g., low degree of processing, freedom from additives). A high degree of processing [99] and the use of additives [100] have been shown to be associated with a reduction in food quality. Health-related concerns of consumers which are associated with the use of additives [107] and a high degree of processing [108] can also explain the probands' ambivalent attitude with regard to health harmlessness. An ambivalent attitude to reconstituted meat is also evident regarding the responsible use of foods, the future potential, and the respect towards farmers. It is known that consumers consider the use of residual materials to produce other products as being important for future food production [77]. In addition, the use of by-products resulting from cutting for human nutrition can be regarded as respectful and responsible due to the high level of specialization of meat consumption [3]. However, compared to muscle meat, reconstituted meat has a different product identity [56] and its meat content is only 90 to $95 \%$ [55]. When it is known that reconstituted meat is used instead of muscle meat without adequate declaration (as has happened in the past, cf. [109]), it may lead to feelings of being deceived [56]. As a consequence, the existing skepticism of German consumers towards the food industry [16] may be increased and the long-term establishment of reconstituted meat products can be complicated. The production of reconstituted meat was evaluated by the participants in this study as being rather economically profitable. This is certainly in line with the fact that the yield of an animal carcass can be increased by producing reconstituted meat. In addition, cost advantages are possible in the food industry by using reconstituted meat products instead of just muscle meat [110].

\subsection{Comparison of the Options for the Efficient Utilization of Plant-based Foods}

The significantly more positive proband evaluation of non-standard fruits/vegetables compared to "leaf-to-root" (with the exception of the dimension of economic profitability) and the production of 
valuable substances from plant-based by-products is attributable to the consumers' general greater familiarity with non-standard fruits/vegetables. This is partly due to the public discussion about food waste [1] as well as the increasing availability of non-standard fruits/vegetables: for example, in retail sales campaigns [24]. Moreover, non-standard fruits/vegetables are whole fruits and in comparison to "second cuts" ("leaf-to-root" principle) or the by-products arising in the food processing industry, these are perceived much less as by-products and are less associated with waste $[8,14]$. The significantly more positive evaluation of non-standard fruits/vegetables and "leaf-to-root" compared to the production of valuable substances from plant-based by-products on all dimensions could be due to the fact that non-standard fruits/vegetables and "second cuts" are natural products, which are eaten or prepared in their unprocessed form. The available studies show that consumers have a clear preference for natural foods $[106,111]$. In contrast, the use of food technologies is associated with consumer-sided concerns [17], which could therefore also have affected the evaluation of valuable substances made from plant-based by-products as they are produced by means of food and biotechnological processing.

\subsection{Comparison of the Options for the Efficient Utilization of Animal-based Foods}

"Nose-to-tail" was evaluated by the probands significantly more positively in comparison to mechanically separated meat (on all dimensions) and reconstituted meat (on seven dimensions, with the exception of economic profitability). A reason for the more positive evaluation of "nose-to-tail" could be that the parts of the slaughtered animal are used in their natural form for food preparation. In contrast, mechanically separated meat and reconstituted meat are products that are subjected to a manufacturing process and are enriched with additives (cf. Sections 1.2 and 4.1). As already explained, consumers have a preference for naturalness in food and a low level of processing as well as the absence of additives are regarded as indicators for that [106]. Conversely, a high degree of processing and the enrichment with additives are associated with a reduced food quality by consumers $[99,100]$. In addition, reconstituted meat was evaluated more negatively on five dimensions (with the expectation of health harmlessness, economic profitability, and hygiene) in comparison to mechanically separated meat. Reconstituted meat has more often been the subject of negative public reporting than mechanically separated meat. The various incidents of missing or false declaration of reconstituted meat (e.g., [112]; cf. Section 4.1) may have contributed to a stronger feeling of deception among consumers and a significant loss of confidence in these products.

\subsection{Comparison of the Options for the Efficient Utilization of Plant-based and Animal-based Foods}

Non-standard fruits/vegetables and "leaf-to-root" were evaluated in the present study significantly more positively than all three options of the efficient use of animal-based foods (except for the dimension of economic profitability, where non-standard fruits/vegetables and "leaf-to-root" showed higher mean values only compared to mechanically separated meat). Studies on foods with which consumers are not very familiar have shown that products of animal origin are more strongly rejected than those of non-animal origin. Disgust as well as a higher pathogenic risk are possible reasons for this reaction $[113,114]$. In contrast, fruits and vegetables as plant-based foods are characterized by a healthier, more positive image [115]. Compared to mechanically separated meat and reconstituted meat, non-standard fruits and vegetables and "second cuts" are 'natural' foods that are more preferred by consumers [106]. Non-standard fruits/vegetables, "leaf-to-root", and "nose-to-tail" are all natural products. However, non-standard fruits/vegetables are becoming more and more frequently available and "second cuts" are often components of purchased fruits/vegetables (e.g., peels, stalks). In contrast, the normally unconsumed parts of slaughtered animals are rarely available to the end-consumer [47], a state that can be regarded by the consumers as an indicator of reduced food safety [92]. In addition, there are consumer concerns regarding the contamination of meat (and especially offal) with heavy metals, which can lead to a critical consumer evaluation or an avoidance of the products [86].

The production of valuable substances from plant-based by-products was evaluated by the probands significantly more positively than reconstituted and mechanically separated meat. 
Manufacturing processes are necessary for the production of valuable substances from plant-based by-products as well as for reconstituted and mechanically separated meat (cf. Sections 1.1 and 1.2). Regarding the production of valuable substances from plant-based by-products, the probands showed an overall rather ambivalent attitude. But in comparison to reconstituted meat and mechanically separated meat the production of valuable substances from plants is evaluated more positively. In general, consumers are unfamiliar with the production of valuable substances from plant-based by-products. The substances are perceived as being innovative. It would have been difficult for our probands to make a clear evaluation of the production processes and the produced substances due to their lack of knowledge about them. This inability to make a clear classification into existing cognitive schemes [79] leads to a rather ambivalent attitude in the consumer. In contrast, reconstituted and mechanically separated meat had already been available on the market for a longer time so that the probands already had information about or experiences with these products and so could evaluate them. Especially various incidents that have been discussed in the media (e.g., misdeclaration of reconstituted meat, use of inferior raw materials for mechanically separated meat, etc.; cf. Section 4.1) may have had a negative impact on the evaluation (e.g., quality) of these products/the options of efficient utilization. The production of valuable substances from plant-based by-products was evaluated as being more promising for the future than "nose-to-tail" in this study. Despite reservations, consumers in general recognize the importance and necessity of innovative technologies for the future food production [77]. Due to this reason, the future potential of the production of valuable substances from plant-based by-products was also estimated to be higher than from "nose-to-tail" in the present study.

\section{Conclusions}

Overall, the results show that the different options of efficient utilization of foods were evaluated very differently by the participants in the present study and were therefore accepted to varying degrees. Three main results can be revealed: (1) In general, the options of efficient utilization of plant-based foods (especially non-standard fruits/vegetables and "leaf-to-root") were evaluated more positively than the options of complete utilization of animal-based foods. An analysis of the literature indicates that the reasons for this may be the rather low confidence in the meat industry, the perceived higher pathogenic risk, and disgust. In contrast, fruits and vegetables are characterized by a healthier, more positive image. (2) If the options of holistic use of plant-based and animal-based foods are considered separately, the options using by-products in their natural form (non-standard fruits/vegetables, "leaf-to-root", and "nose-to-tail") were evaluated more positively in comparison to those options which subjected the by-products to some form of processing (reconstituted meat, mechanically separated meat, and valuable substances from plant-based by-products). These results indicate a strong preference for naturalness in food, for low levels of processing and for the absence of additives. (3) Regarding the options that use processing operations, the proband's familiarity with processes or the food technologies was also of high importance. When technologies or products were novel for the participants, it was difficult for them to give clear indications and an ambivalent attitude was observed (e.g., valuable substances from plant-based by-products). Processing operations and products that were already established were evaluated more clearly due to the proband's previous knowledge and experiences (reconstituted meat, mechanically separated meat).

In general, the present findings provide a useful addition to the consumer-related study of efficient food utilization. Until now, there are only individual studies available which shed light on options of efficient food utilization from a consumer's point of view (cf. Section 1). The findings of the present study connect to these studies and provide further insight into the consumer acceptance of possibilities of efficient utilization. Further, they enable a comparison between different options of efficient utilization of food on the basis of predefined criteria.

The high relevance of naturalness for consumers [106,111] is also evident with regard to by-products. In addition, findings of the present study, which support the positive evaluation of utilizing plant-based by-products (especially non-standard fruits/vegetables and "leaf-to-root"), connect 
to findings confirming the high value and benefits attached to fruits and vegetables by consumers. For instance, consumers use different strategies in everyday life to minimize deterioration and wastage of fruits [116]. The already proven more critical consumer view of animal-based foods $[113,114]$ compared to plant-based foods is, according to the findings of the present study, also transferable to by-products.

Available studies show an increasing food-related sustainability orientation [9] and an awareness of food waste issues [1] among consumers. Nevertheless, the results of the present study also confirm a considerable consumer skepticism especially regarding the efficient utilization of animal-based by-products. These results connect to findings on non-standard fruits/vegetables, showing that consumers interest and openness towards the topic of food waste is not consistently translated into their purchasing behavior [26]. There is a need for further research in this context.

Various managerial implications can be derived from the findings of the present study. It shows that the various options of efficient utilization of foods differ significantly regarding consumer acceptance. Accordingly, when manufacturing goods based on by-products, the consumer acceptance of each product should be carefully evaluated before its market launch. In case of a lack of acceptance, existing acceptance barriers could be identified.

The study also shows that the naturalness of a by-product has a positive effect on consumer acceptance, with non-standard fruits/vegetables and "leaf-to-root" being evaluated more positively than "nose-to-tail". Increasing availability of animal-based by-products in retail could have a positive effect on consumer acceptance. In addition to the development of a greater familiarity with the products [117], consumer fears concerning food safety resulting from product unavailability [92] could be allayed.

The present study shows that consumers can have difficulties evaluating innovative foodstuffs that originate from by-products, and that are manufactured using new technologies (ambivalent evaluation of innovative valuable substances from plant-based by-products). This might be the case because an integration into existing cognitive schemata is impossible. In this situation, producers can influence the decision-making behavior by providing specific cues which help consumers to evaluate the product [8].

In general, strategies for the reduction of food waste are a frequently debated topic. Basically, industry and retailing have an economic interest in reducing food waste. However, this is difficult in the case of by-products from the meat industry. Our results also showed a considerable skepticism regarding all three options of efficient utilization of animal-based foods. The skepticism around sausage production (utilization of animal-based by-products) is, historically speaking, by no means a novelty. However, the multitude of meat scandals, e.g., the BSE crisis or the rotten meat scandal, is likely to have updated the existing distrust even further $[16,118]$. Even though there is a huge reduction potential for food waste $[119,120]$, it is harder to achieve than it appears at first glance. The findings of our study, which used an information treatment, provide factual indications for this. As a practical implication of the findings of this study, it can be said that simple information campaigns will not overcome the widespread distrust. Rather, a comprehensive approach that includes transparency [121-123] and trust management $[122,124]$ as well as the transmission of price benefits, whose relevance has been shown in studies regarding non-standard fruits/vegetables [26,29] seems necessary.

There are also some study limitations that need to be acknowledged. Due to a time limitation of the questionnaire, we could not consider more than six options of efficient utilization in the survey. Still, there are various other possibilities of efficient food utilization that have not been investigated, or have been investigated only to a limited extent from a consumer's point of view. Moreover, only eight criteria or dimensions could be included to evaluate each option of efficient utilization. Other additional aspects would have been important here. The fact that each of the eight evaluation criteria is queried exclusively by one item can also be regarded as limiting. The inclusion of multi-item scales for querying each aspect was not possible for reasons mentioned above. The use of single-item scales in cross-sectional studies is associated with some disadvantages compared to multi-item scales. Among other things, it is not possible to determine reliability [125]. Furthermore, the study focused on consumer evaluation. Aspects that determine the evaluations were not taken into account. 
In further studies, other possibilities of efficient food utilization as well as additional criteria to evaluate the options of efficient food utilization could be used. Due to the fact that options including innovative technologies gain importance, they should be taken in particular account in further studies. In addition, follow-up studies could focus on how consumer acceptance of different food utilization options is influenced. So far, initial findings on non-standard fruits/vegetables are available [27-29].

In the present study, the probands received neutral information about the options of efficient food utilization on which the evaluation was based. In follow-up studies, it would be interesting to examine the extent to which further information influence consumer evaluation. According to Bruhn [6], a successful establishment of innovative products is likely, if they are associated with tangible advantages. Accordingly, the influence of available and appropriate information on consumer acceptance of the products could be tested (e.g., the production of valuable substances from plant-based by-products is carried out without genetic engineering).

The present study demonstrates clear acceptance differences between the various options of efficient utilization of foods. This result points towards the need for a more differentiated investigation of possibilities in this respect. Further research could include the development of a comprehensive questionnaire investigating consumer evaluations of efficient food utilization options or innovative, by-product based food items. The questionnaire could be applied both in practice and scientific research.

Author Contributions: Conceptualization of the study, S.N. and A.S.; analysis of the empirical data, S.N.; writing-original draft preparation, S.N.; contribution of references, comments and revisions to the original draft as well as substantive intellectual contributions to the content, A.S.

Funding: The present study was carried out within the project "Bioeconomy 2.0: Innovation potentials of secondary streams of food production". This project was funded by the Ministry of Science and Culture of Lower Saxony (the so-called "Niedersächsisches Vorab"). In addition, we acknowledge support by the German Research Foundation and the Open Access Publication Funds of the Göttingen University.

Acknowledgments: The authors would like to thank the Ministry of Science and Culture of Lower Saxony for the financial support (the so-called "Niedersächsisches Vorab") of the project "Bioeconomy 2.0: Innovation potentials of secondary streams of food production". The present study was carried out within this project.

Conflicts of Interest: The authors declare no conflict of interest.

\section{References}

1. Aschemann-Witzel, J.; de Hooge, I.; Amani, P.; Bech-Larsen, T.; Oostindjer, M. Consumer-related food waste: Causes and potential for action. Sustainability 2015, 7, 6457-6477. [CrossRef]

2. Hang, Y.D. Management and utilization of food processing wastes. J. Food Sci. 2004, 69, CRH104-CRH107. [CrossRef]

3. Dirscherl, C. Fleischkonsum und Tierhaltung in der aktuellen gesellschaftlichen Debatte. Ber. über Landwirtsch. -Z. für Agrarpolit. Landwirtsch. 2013, 91, 1-14.

4. Klöck, G.; Noke, A. Veredlungsprodukte aus ungenutzten Stoffströmen der Lebensmittelverarbeitung. In Industrial Ecology, 1st ed.; Gleich, V.A., Gößling-Reisemann, S., Eds.; Vieweg + Teubner Verlag: Wiesbaden, Germany, 2008; pp. 88-96.

5. Galanakis, C.M. Sustainable Food Systems from Agriculture to Industry, 1st ed.; Academic Press: London, UK, 2018.

6. Bruhn, C.M. Consumer acceptance of food innovations. Innov. Manag. Policy 2008, 10, 91-95. [CrossRef]

7. Herbig, P.A.; Day, R.L. Consumer acceptance: The key to successful introductions of innovations. Mark. Intell. Plan. 1992, 10, 4-15. [CrossRef]

8. Bhatt, S.; Lee, J.; Deutsch, J.; Ayaz, H.; Fulton, B.; Suri, R. From food waste to value-added surplus products (VASP): Consumer acceptance of a novel food product category. J. Consum. Behav. 2017, 17, 57-63. [CrossRef]

9. Verain, M.C.D.; Bartels, J.; Dagevos, H.; Sijtsema, S.J.; Onwezen, M.C.; Antonides, G. Segments of sustainable consumers: A literature review. Int. J. Consum. Stud. 2012, 36, 123-132. [CrossRef]

10. Wheale, P.; Hinton, D. Ethical consumers in search of markets. Bus. Strat. Environ. 2007, 16, 302-315. [CrossRef]

11. BMEL. Deutschland, Wie es isst. Der BMEL-Ernährungsreport 2018, 1st ed.; Bundesministerium für Ernährung und Landwirtschaft: Berlin, Germany, 2017. 
12. Neff, R.A.; Spiker, M.L.; Truant, P.L. Wasted food: US consumers' reported awareness, attitudes, and behaviors. PLOS ONE 2015, 10, e0127881. [CrossRef]

13. Pollard, J.; Kirk, S.F.L.; Cade, J.E. Factors affecting food choice in relation to fruit and vegetable intake: A review. Nutr. Res. Rev. 2002, 15, 373-387. [CrossRef]

14. Frewer, L.J.; Gremmen, B. Consumer's interests in food processing waste management und co-product recovery. In Handbook of Waste Management and Co-Product Recovery, 1st ed.; Waldron, K., Ed.; Woodhead Publishing: Cambridge, UK, 2007; pp. 21-33.

15. Menegaki, A.N.; Mellon, R.C.; Vrentzou, A.; Koumakis, G.; Tsagarakis, K.P. What's in a name: Framing treated wastewater as recycled water increases willingness to use and willingness to pay. J. Econ. Psychol. 2009, 30, 285-292. [CrossRef]

16. SGS. Vertrauen und Skepsis: Was leitet die Deutschen beim Lebensmitteleinkauf? SGS-Verbraucherstudie 2014: Ergebnisse einer bevölkerungsrepräsentativen Befragung, 1st ed.; SGS Germany GmbH: Hamburg, Germany, 2014.

17. Frewer, L.J.; Bergmann, K.; Brennan, M.; Lion, R.; Meertens, R.; Rowe, G.; Siegrist, M.; Vreijken, C. Consumer response to novel agri-food technologies: Implications for predicting consumer acceptance of emerging food technologies. Trends Food Sci. Technol. 2011, 22, 442-456. [CrossRef]

18. Leaf to Root. Nose to Tail for Veggies. Available online: https://leaf-to-root.com/ (accessed on 4 May 2019).

19. Vom Blatt bis zur Wurzel. Obst und Gemüse komplett verwenden? Available online: https://www.bzfe.de/ inhalt/vom-blatt-bis-zur-wurzel-31270.html (accessed on 1 June 2019).

20. Hollmer, K. Kraut mit Rüben. Süddeutsche Zeitung. 24 June 2018, pp. 1-3. Available online: https: //www.sueddeutsche.de/stil/essen-und-trinken-kraut-mit-rueben-1.4024913 (accessed on 30 August 2019).

21. Kays, S.J. Preharvest factors affecting appearance. Postharvest Biol. Technol. 1999, 15, 233-247. [CrossRef]

22. Council of the European Union. Commission implementing regulation (EU) No 543/2011 of 7 June 2011 Laying Down Detailed Rules for the Application of Council Regulation (EC) No 1234/2007 in Respect of the Fruit and Vegetables and Processed Fruit and Vegetables Sectors; Council of the European Union: Brussels, Belgium, 2011.

23. Aunkofer, F. Erhebung von Lebensmittelverlusten im Ökologischen Gemüsebau—Ein Überblick zur Biologischen Gemüseproduktion in Deutschland und Österreich, 1st ed.; AV Akademikerverlag: Riga, Latvia, 2015.

24. Louis, D.; Lombart, C. Retailers' communication on ugly fruits and vegetables: What are consumers' perceptions? J. Retail. Consum. Serv. 2018, 41, 256-271. [CrossRef]

25. Jaeger, S.R.; Machín, L.; Aschemann-Witzel, J.; Antúnez, L.; Harker, F.R.; Ares, G. Buy, eat or discard? A case study with apples to explore fruit quality perception and food waste. Food Qual. Prefer. 2018, 69, 10-20. [CrossRef]

26. Di Muro, M.; Wongprawmas, R.; Canavari, M. Consumers' preferences and willingness-to-pay for misfit vegetables. Econ. Agro Aliment. 2016, 18, 133-154. [CrossRef]

27. Loebnitz, N.; Schuitema, G.; Grunert, K.G. Who buys oddly shaped food and why? Impacts of food shape abnormality and organic labeling on purchase intentions. Psychol. Mark. 2015, 32, 408-421. [CrossRef]

28. Loebnitz, N.; Grunert, K.G. The effect of food shape abnormality on purchase intentions in China. Food Qual. Prefer. 2015, 40, 24-30. [CrossRef]

29. De Hooge, I.E.; Oostindjer, M.; Aschemann-Witzel, J.; Normann, A.; Loose, S.M.; Almli, V.L. This apple is too ugly for me! Consumer preferences for suboptimal food products in the supermarket and at home. Food Qual. Prefer. 2017, 56, 80-92. [CrossRef]

30. Carle, R.; Schieber, A. Gewinnung funktioneller Lebensmittelinhaltsstoffe aus Reststoffen der Karottensaftund Apfelsaftproduktion. Ernährungsumschau 2006, 53, 348-352.

31. Russ, W.; Schnappinger, M. Waste related to the food industry: A challenge in material loops. In Utilization of By-Products and Treatment of Waste in the Food Industry, 1st ed.; Oropoulou, V., Russ, W., Eds.; Springer: Boston, MA, USA, 2007; Volume 3, pp. 1-13.

32. Schieber, A.; Stintzing, F.C.; Carle, R. By-products of plant food processing as a source of functional compounds-Recent developments. Trends Food Sci. Technol. 2001, 12, 401-413. [CrossRef]

33. Berger, R.G. Biotechnology as a source of natural volatile flavours. Curr. Opin. Food Sci. 2015, 1, 38-43. [CrossRef]

34. Bosse, A.K.; Fraatz, M.A.; Zorn, H. Formation of complex natural flavours by biotransformation of apple pomance with basidiomycetes. Food Chem. 2013, 141, 2952-2959. [CrossRef] [PubMed]

35. Sagar, N.A.; Pareek, S.; Sharma, S.; Yahia, E.M.; Lobo, M.G. Fruit and vegetable waste: Bioactive compounds, their extraction, and possible utilization. Compr. Rev. Food Sci. F 2018, 17, 512-531. [CrossRef] 
36. Inácio, F.D.; Ferreira, R.O.; vaz de Araujo, C.A.; Peralta, R.M.; Marques de Souza, C.G. Production of enzymes and biotransformation of orange waste by oyster mushroom, Pleurotus pulmonarius (Fr.) Quel. Adv. Microbiol. 2015, 5, 1-8.

37. Johnson, E.A. Biotechnology of non-Saccharomyces yeasts-The basidiomycetes. Appl. Microbiol. Biotechnol. 2013, 97, 7563-7577. [CrossRef]

38. Stadler, M.; Hoffmeister, D. Fungal natural products-The mushroom perspective. Front. Microbiol. 2015, 6, 1-4. [CrossRef]

39. Berger, R.G. Bioökonomische Lebensmittelproduktion. GoingPublic Magazin Sonderausgabe Biotechnologie 2012, 14, 74-75.

40. Georget, E.; Miller, B.; Callanan, M.; Heinz, V.; Mathys, A. (Ultra) high pressure homogenization for continuous high pressure sterilization of pumpable foods-A review. Front. Nutr. 2014, 1, 1-6. [CrossRef]

41. Mathys, A.; Toepfl, S. Pulsed electric fields for improving mass transfer. South. Afr. Food Sci. Technol. Mag. 2012, 2, 41-43.

42. Linke, D.; Berger, R.G. Foaming of proteins: New prospects for enzyme purification processes. J. Biotechnol. 2011, 152, 125-131. [CrossRef] [PubMed]

43. Berger, R.G. Volatile flavours through enzyme catalysis. In Flavour Science, Proceedings of the XIV Weurman Flavour Research Symposium, Weurman Flavour Research Symposium, Cambridge, UK, 15-19 September 2014; Taylor, A., Mottram, D., Eds.; Context Products: Packington, UK, 2015; pp. 169-176.

44. Von der Schnauze bis zum Schwanz. Available online: https:/www.nabu.de/umwelt-und-ressourcen/ oekologisch-leben/essen-und-trinken/fleisch/22927.html (accessed on 10 May 2019).

45. Jayathilakan, K.; Sultana, K.; Radhakrishna, K.; Bawa, A.S. Utilization of byproducts and waste materials from meat, poultry and fish processing industries: A review. J. Food Sci. Techol. 2012, 49, 278-293. [CrossRef] [PubMed]

46. Von Greve-Dierfeld, A. Esst mehr Augen, Schweinedarm und Entenfüße! Stern. 26 February 2015. Available online: https:/www.stern.de/genuss/trends/from-nose-to-tail--wenn-sich-sternekoeche-zu-allesverwerternweiterbilden-5947596.html (accessed on 30 August 2019).

47. Tucker, C.A. The significance of sensory appeal for reduced meat consumption. Appetite 2014, 81, 168-179. [CrossRef]

48. Council of the European Union. Regulation (EC) No 853/2004 of the European Parliament and of the Council of 29 April 2004 Laying Down Specific Hygiene Rules for Food of Animal Origin; The European Parliament and the Council of the European Union: Brussels, Belgium, 2004.

49. Separatorenfleisch. Available online: https://www.lgl.bayern.de/lebensmittel/warengruppen/wc_07_ fleischerzeugnisse/et_separatorenfleisch.htm (accessed on 30 August 2019).

50. Council of the European Union. Regulation (EU) No 1169/2011 of the European Parliament and of the Council of 25 October 2011; The European Parliament and the Council of the European Union: Brussels, Belgium, 2011.

51. Meat Produced by Advanced Meat/Bone Separation Machinery and Meat Recovery (AMR) systems. Available online: https://www.federalregister.gov/documents/2004/01/12/04-626/meat-produced-by-advanced-meatboneseparation-machinery-and-meat-recovery-amr-systems (accessed on 19 August 2019).

52. Meat and poultry labeling terms. Available online: https://www.fsis.usda.gov/wps/portal/fsis/topics/foodsafety-education/get-answers/food-safety-fact-sheets/food-labeling/meat-and-poultry-labeling-terms/ meat-and-poultry-labeling-terms (accessed on 19 August 2019).

53. USDA. Authenticated, U.S. Government Information, Federal Register, Vol. 60, No. 213/November 3, 1995; USDA: Washington, DC, USA, 1995.

54. Vollmer, G.; Josst, G.; Schenker, D.; Sturm, W.; Vreden, N. Lebensmittelführer: Inhalte, Zusätze, Rückstände, 3rd ed.; Thieme Verlag: Stuttgart, Germany, 2007.

55. Leitsätze für Fleisch und Fleischerzeugnisse. Available online: https://www.bmel.de/SharedDocs/Downloads/ Ernaehrung/Lebensmittelbuch/LeitsaetzeFleisch.pdf?_blob=publicationFile (accessed on 30 August 2019).

56. Zühlsdorf, A.; Spiller, A. Grauzone Lebensmittelkommunikation: Empirische Studie zur Verbraucherwahrnehmung im Spannungsfeld von Informationsanforderungen und Aufmerksamkeitsregeln, 1st ed.; University of Göttingen and Agrifood Consulting GmbH: Göttingen, Germany, 2012.

57. Menold, N.; Bogner, K. Gestaltung von Ratingskalen in Fragebögen (Version 1.1). Working paper. Gestaltung von Ratingskalen in Fragebögen (Version 1.1). GESIS Survey Guidelines; GESIS Leibnitz-Institut für Sozialwissenschaften: Mannheim, Germany, 2015. 
58. Prüfer, P.; Vazansky, L.; Wystup, D. Antwortskalen im ALLBUS und ISSP: Eine Sammlung (ZUMA-Methodenbericht, 2003/11); Zentrum für Umfragen, Methoden und Analysen-ZUMA: Mannheim, Germany, 2003.

59. Goldhammer, F.; Hartig, J. Interpretation von Testresultaten und Testeichung. In Testtheorie und Fragebogenkonstruktion, 2nd ed.; Moosbrugger, H., Kelava, A., Eds.; Springer: Berlin/Heidelberg, Germany, 2012; pp. 172-201.

60. Giersdorf, N.; Loh, A.; Bieber, C.; Caspari, C.; Deinzer, A.; Doering, T.; Eich, W.; Hamann, J.; Heesen, C.; Kasper, J.; et al. Entwicklung eines Fragebogens zur Partizipativen Entscheidungsfindung. Bundesgesundheitsblatt Gesundh. Gesundh. 2004, 47, 969-976.

61. Rasch, B.; Friese, M.; Hofmann, W.; Naumann, E. Quantitative Methoden. Band 2, 3rd ed.; Springer: Heidelberg, Germany, 2010.

62. Göbel, C.; Langen, N.; Blumenthal, A.; Teitscheid, P.; Ritter, G. Cutting food waste through cooperation along the food supply chain. Sustainability 2015, 7, 1429-1445. [CrossRef]

63. Creusen, M.E.H.; Schoormans, J.P.L. The different roles of product appearance in consumer choice. J. Prod. Innov. Manag. 2005, 22, 63-81. [CrossRef]

64. Stuart, T. Waste: Uncovering the Global Food Scandal, 1st ed.; W.W. Norton \& Company Ltd.: New York, NY, USA, 2009.

65. Normann, A.; Wendin, K.; Röding, M.; Bolos, L.A.; Lagerkvist, C.J. Influence of Color, Shape and Damages on Consumer Preferences and Perceived Sensory Attributes on Sub-Optimal Apples, 1st ed.; Rise Research Institutes of Sweden: Gothenburg, Sweden, 2018.

66. Bunn, D.; Feenstra, G.W.; Lynch, L.; Sommer, R. Consumer acceptance of cosmetically imperfect produce. J. Consum. Aff. 1990, 24, 268-279. [CrossRef]

67. Schneider, F. Lebensmittel im Abfall-Mehr als eine technische Herausforderung. Ländlicher Raum 2008, 1, $1-15$.

68. Neff, R.A.; Kanter, R.; Vandevijvere, S. Reducing food loss and waste while improving the public's health. Health Aff. 2015, 34, 1821-1829. [CrossRef] [PubMed]

69. Priefer, C.; Jörissen, J. ITA-Monitoring "Frisch auf den Müll". Verringerung der Lebensmittelverluste als Ansatz zur Verbesserung der Welternährungssituation; Karlsruher Institut für Technologie: Karlsruhe, Germany, 2012.

70. Gustavsson, J.; Cederberg, C.; Sonesson, U. Global Food Losses and Food Waste-Extent, Causes and Prevention; FAO: Rome, Italy, 2011.

71. Rohlf, S. Mit Strunk und Stiel. Wegwerfen ist von gestern. Auch, was Obst und Gemüse betrifft. "Leaf to root" heißt der neue Küchentrend. Berliner Zeitung. 14 July 2018. Ausgabe 162, S. AM10. Available online: https://www.berliner-zeitung.de/berlin/freizeit/kuechentrend--leaf-to-root---vom-blatt-bis-zur-wurzelwird-alles-gegessen-30954924 (accessed on 30 August 2019).

72. BfR. BfR-Verbrauchermonitor 02/2018, 1st ed.; Bundesinstitut für Risikobewertung: Berlin, Germany, 2018.

73. Herbst, M. Verwerten statt verschwenden. Wegwerfen ist keine Option. FAZ.NET. 30 April 2017. Available online: https:/www.faz.net/aktuell/stil/essen-trinken/lebensmittel-warum-wegwerfen-keine-option-ist14983438.html (accessed on 30 August 2019).

74. Siegrist, M. Factors influencing public acceptance of innovative food technologies and products. Trends Food Sci. Technol. 2008, 19, 603-608. [CrossRef]

75. Cardello, A. Consumer concerns and expectations about novel food processing technologies: Effects of product liking. Appetite 2003, 40, 217-233. [CrossRef]

76. Lätheenmäki, L.; Grunert, K.; Ueland, O.; Astrom, A.; Arvola, A.; Bech-Larsen, T. Acceptability of genetically modified cheese presented as real product alternative. Food Qual. Prefer. 2002, 13, 523-533. [CrossRef]

77. Hengse, A.; Bücking, M. Essbare Innovationen. Lebensmittel im Spannungsfeld von technologischem Fortschritt und Technikablehnung unter Verbrauchern, 1st ed.; Fraunhofer-Allianz Food Chain Management: Schmallenberg, Germany, 2015.

78. Moodie, R.; Stuckler, D.; Monteiro, C.; Sheron, N.; Neal, B.; Thamarangsi, T.; Lincoln, P.; Casswell, S.; Lancet NCD Action Group. Profits and pandemics: Prevention of harmful effects of tobacco, alcohol, and ultra-processed food and drink industries. Lancet 2013, 381, 670-679. [CrossRef]

79. Moreau, C.P.; Markman, A.B.; Lehmann, D.R. “What is it?" Categorization flexibility and consumer responses to really new products. J. Consum. Res. 2001, 27, 489-498. [CrossRef]

80. Köster, E.P. Diversity in the determinants of food choice: A psychological perspective. Food Qual. Prefer. 2009, 20, 70-82. [CrossRef] 
81. Henchion, M.; McCarthy, M.; O'Callaghan, J. Transforming beef by-products into valuable ingredients: Which spell/recipe to use? Front. Nutr. 2016, 3, 53. [CrossRef] [PubMed]

82. Who Are the Modern Offal Eaters? Available online: http://www.offalgood.com/uncategorized/who-are-themodern-offal-eaters.html (accessed on 30 August 2019).

83. Nollet, L.M.L.; Toldrá, F. Handbook of Analysis of Edible Animal By-Products, 1st ed.; CRC Press: Boca Raton, FL, USA, 2011.

84. BfR. Jahresbericht 2013, 1st ed.; Bundesinstitut für Risikobewertung: Berlin, Germany, 2013.

85. Kher, S.V.; De Jonge, J.; Wentholt, M.T.A.; Deliza, R.; de Andrade, J.C.; Cnossen, H.J.; Luijckx, N.B.L.; Frewer, L.J. Consumer perceptions of risks of chemical and microbiological contaminants associated with food chains: A cross-national study. Int. J. Consum. Stud. 2013, 37, 73-83. [CrossRef]

86. Koch, S.; Lohmann, M.; Epp, A.; Böl, G.-F. Risikowahrnehmung von Kontaminanten in Lebensmitteln. Bundesgesundheitsblatt Gesundheitsforschung Gesundheitsschutz 2017, 60, 774-782. [CrossRef] [PubMed]

87. Zühlsdorf, A.; Spiller, A.; Gauly, S.; Kühl, S. Wie wichtig ist Verbrauchern das Thema Tierschutz? Präferenzen, Verantwortlichkeiten, Handlungskompetenzen und Politikoptionen, 1st ed.; Zühldorf and Partner: Göttingen, Germany, 2016.

88. Laroche, M.; Bergeron, J.; Barbaro-Forleo, G. Targeting consumers who are willing to pay more for environmentally friendly products. J. Consum. Mark. 2001, 18, 503-520. [CrossRef]

89. Vilgis, T. Was wir essen dürfen oder: Wie molekular ist die Ethik? In Was der Mensch essen darf, 1st ed.; Hirschfelder, G., Ploeger, A., Rückert-John, J., Schönberger, G., Eds.; Springer VS: Wiesbaden, Germany, 2015; pp. 145-155.

90. Beardsworth, A.; Keil, T. Sociology on the Menu. An Invitation to the Study of Food and Society, 1st ed.; Routledge: New York, NY, USA, 1997.

91. Dodds, W.B.; Monroe, K.B. The effect of brand and price information on subjective product evaluations. Adv. Consum. Res. 1985, 12, 85-90.

92. Ruby, M.B.; Heine, S.J. Too close to home. Factors predicting meat avoidance. Appetite 2012, 59, 47-52. [CrossRef] [PubMed]

93. Toldrá, F.; Aristoy, M.-C.; Mora, L.; Reig, M. Innovations in value-addition of edible meat by-products. Meat Sci. 2012, 92, 290-296. [CrossRef] [PubMed]

94. Council of the European Union. Regulation (EC) No 999/2001 of the European Parliament and of the Council of 22 May 2001 Laying Down Rules for the Prevention, Control and Eradication of Certain Transmissible Spongioform Encephalopathies; The European Parliament and the Council of the European Union: Brussels, Belgium, 2001.

95. Council of the European Union. Regulation (EC) No 1923/2006 of the European Parliament and the Council of 18 December 2006 Amending Regulation (EC) No 999/2001 Laying Down Rules for the Prevention, Control and Eradication of Certain Transmissible Spongiform Encephalopaties; The European Parliament and the Council of the European Union: Brussels, Belgium, 2006.

96. Separatorenfleisch zählt nicht als Fleisch. Available online: https://www.lebensmittelklarheit.de/ informationen/separatorenfleisch-zaehlt-nicht-als-fleisch (accessed on 30 August 2019).

97. Frankfurter Allgemeine Zeitung. Es wird auch Fleisch geliefert, das schon grün ist. FAZ.NET. 6 November 2013. Available online: https://www.faz.net/aktuell/gesellschaft/kriminalitaet/verdacht-auf-neuen-fleischskandal-eswird-auch-fleisch-geliefert-das-schon-gruen-ist-12651327.html (accessed on 30 August 2019).

98. BfR. Separatorenfleisch: Der Grad der Veränderung der Muskelfaserstruktur ist für die Einstufung unerheblich, 1st ed.; Bundesinstitut für Risikobewertung: Berlin, Germany, 2006.

99. EUFIC. EUFIC Forum $n^{\circ}$ 7-Understanding Perceptions of Processed Food Among UK Consumers. A Qualitative Consumer Study by EUFIC; EUFIC: Brussels, Belgium, 2016.

100. Williams, P.; Stirling, E.; Keynes, N. Food fears: A national survey on the attitudes of Australian adults about the safety and quality of food. Asia Pac. J. Clin. Nutr. 2004, 13, 32-39. [PubMed]

101. Bundesamt für Lebensmittelsicherheit und Veterinärwesen BVL. Informationsschreiben 2019/1: Auslegung des Begriffs «Separatorenfleisch» aus Rohstoffen von Geflügel, 1st ed.; Bundesamt für Lebensmittelsicherheit und Veterinärwesen: Bern, Switzerland, 2019.

102. Animal-Based Foods Are More Resource-Intensive than Plant-Based Foods. Available online: https://www.wri. org/resources/charts-graphs/animal-based-foods-are-more-resource-intensive-plant-based-foods (accessed on 4 May 2019). 
103. Frankfurter Rundschau. Imitat-Käse auf dem Teller; Main-Taunus Veterinäramt deckt wieder Verstöße in Restaurants auf. Frankfurter Rundschau, 18 December 2009; R19.

104. Bebenburg, P. Der Ekel-Reflex. Frankfurter Rundschau, 9 December 2009; R4.

105. Der Spiegel. Halb vorgekaut. Der Spiegel, 13 February 1984; 75-77.

106. Román, S.; Sánchez-Siles, L.M.; Siegrist, M. The importance of food naturalness for consumers: Results of a systematic review. Trends Food Sci. Technol. 2017, 67, 44-57. [CrossRef]

107. Bearth, A.; Cousin, M.E.; Siegrist, M. The consumer's perception of artificial food additives: Influences on acceptance, risk and benefit perceptions. Food Qual. Prefer. 2014, 38, 14-23. [CrossRef]

108. Szocs, C.; Lefebvre, S. The blender effect: Physical state of food influences healthiness perceptions and consumption decisions. Food Qual. Prefer. 2016, 54, 152-159. [CrossRef]

109. Die Welt. Viele Mogeleien bei Schinken und Käse; Ministerium: Pizzerien und Imbisse mit Ersatzprodukten. Die Welt, 16 July 2009; 36.

110. Frankfurter Allgemeine Zeitung. Trickser in der Tiefkühltruhe. Frankfurter Allgemeine Zeitung, 9 July $2009 ; 15$.

111. Chambers, E.; Chambers, E.; Castro, M. What is "natural"? Consumer response to selected ingredients. Foods 2018, 7, 65. [CrossRef]

112. Heiss und fettig. Taz. die tageszeitung, 29 August 2009; 39.

113. Pliner, P.; Pelchat, M. Neophobia in humans and the special status of foods of animal origin. Appetite 1991, 16, 205-218. [CrossRef]

114. Martins, Y.; Pelchat, M.L.; Pliner, P. “Try it; it's good for you": Effects of taste and nutrition information on willingness to try novel foods. Appetite 1997, 28, 89-102. [CrossRef]

115. Margetts, B.M.; Martinez, J.A.; Saba, A.; Holm, L.; Kearney, M. Definitions of 'healthy' eating: A pan-EU survey of consumer attitudes to food, nutrition and health. Eur. J. Clin. Nutr. 1997, 51, S23-S29.

116. Campbell, R.L.; Smith, B.G.; Jaeger, S.R.; Harker, F.R. Deterioration and disposal of fruit in the home: Consumer interviews and fruit quality assessments. J. Sci Food Agric. 2009, 89, 24-32. [CrossRef]

117. Zajonc, R.B. Attitudinal effects of mere exposure. J. Pers. Soc. Psychol. 1968, 9, 1-27. [CrossRef]

118. Verbeke, W.; Viaene, J.; Guiot, O. Health communication and consumer behavior on meat in Belgium: From BSE until Dioxin. J. Health Commun. 1999, 4, 345-357. [PubMed]

119. Xue, L.; Prass, N.; Gollnow, S.; Davis, J.; Scherhaufer, S.; Östergren, K.; Cheng, S.; Liu, G. Efficiency and carbon footprint of the German meat supply chain. Environ. Sci. Technol. 2019, 53, 5133-5142. [CrossRef]

120. Beretta, C.; Stoessel, F.; Baier, U.; Hellweg, S. Quantifying food losses and the potential for reduction in Switzerland. Waste Manag. 2013, 33, 764-773. [CrossRef] [PubMed]

121. Wognun, P.M.N.; Bremmers, H.; Trienekens, J.H.; van der Vorst, J.G.A.J.; Bloemhof, J.M. Systems for sustainability and traceability of food supply chains-Current status and challenges. Adv. Eng. Inf. 2011, 25, 65-76.

122. Beulens, A.J.M.; Broens, D.-F.; Folstar, F.; Hofstede, G.J. Food safety and transparency in food chains and networks Relationships and challenges. Food Control. 2005, 16, 481-486. [CrossRef]

123. Reisch, L.; Eberle, U.; Lorek, S. Sustainable food consumption: An overview of contemporary issues and policies. Sustain. Sci. Pract. Policy 2013, 9, 7-25. [CrossRef]

124. Pivato, S.; Misani, N.; Tencati, A. The impact of corporate social responsibility on consumer trust: The case of organic food. Bus. Ethics Eur. Rev. 2008, 17, 3-12. [CrossRef]

125. Wanous, J.P.; Reichers, A.E.; Hudy, M.J. Overall job satisfaction: How good are single-item measures? J. Appl. Psychol. 1997, 82, 247-252. [CrossRef]

(C) 2019 by the authors. Licensee MDPI, Basel, Switzerland. This article is an open access article distributed under the terms and conditions of the Creative Commons Attribution (CC BY) license (http://creativecommons.org/licenses/by/4.0/). 